\title{
Sensory Evaluation and Nutritional Composition of Developed Papaya-Gooseberry Jam
}

\author{
Ena Gupta1, Shalini Purwar1, Pragati Jaiswal'2, Reena Chaturvedi², G. K. Rai2 \\ ${ }^{1}$ Centre of Biotechnology, University of Allahabad, Allahabad, India \\ ${ }^{2}$ Centre of Food Technology, University of Allahabad, Allahabad, India \\ Email: enaravish@gmail.com
}

Received 3 February 2016; accepted 20 June 2016; published 23 June 2016

Copyright (C) 2016 by authors and Scientific Research Publishing Inc.

This work is licensed under the Creative Commons Attribution International License (CC BY). http://creativecommons.org/licenses/by/4.0/

cc) (i) Open Access

\begin{abstract}
Jams are delicious and nutritious spreads typically made from fruit, sugar and pectin that ensure availability of fruits in off-season. The study aimed to develop papaya-gooseberry jam and to evaluate sensory and nutritional parameters. Six variations of papaya: gooseberry jam was prepared besides the control $T_{0}\left(100 \%\right.$ papaya). The successive variations were $T_{1}(95: 5), T_{2}(90: 10), T_{3}$ (85:15), $T_{4}(80: 20), T_{5}(75: 25)$ and $T_{6}(70: 30)$. $T$-test and one-way analysis of variance (ANOVA) were applied to find the significant difference in sensory and nutritional parameters in different variations. Among different variations, the treatment $\left(\mathrm{T}_{4}\right)$ was found to be the best on the basis of sensory evaluation with incorporation levels of 80 percent papaya and 20 percent gooseberry. The identified treatment $\left(\mathrm{T}_{4}\right)$ was analyzed for nutritional composition in comparison to control $\left(T_{0}\right)$. Nutritional analysis showed that treatment $\left(T_{0}\right)$ contained maximum energy $(353 \mathrm{Kcal} / 100 \mathrm{~g})$, protein $(0.50 \mathrm{~g} / 100 \mathrm{~g})$, carbohydrate $(87.14 \mathrm{~g} / 100 \mathrm{~g})$, fat $(0.19 \mathrm{~g} / 100 \mathrm{~g})$ and beta-carotene $(195.0$ $\mathrm{g} / \mathbf{1 0 0 \mathrm { g } )}$ whereas the treatment $\left(\mathrm{T}_{4}\right)$ was found to be high in nutrients such as fiber $(1.32 \mathrm{~g} / 100 \mathrm{~g})$, calcium $(92.0 \mathrm{mg} / \mathbf{1 0 0 g})$, phosphorus $(14.13 \mathrm{mg} / 100 \mathrm{~g})$, vitamin $\mathrm{C}(19.16 \mathrm{mg} / \mathbf{1 0 0 g})$ and antioxidant activity $(98.0 \%)$. Thus, results signified that treatment $\left(\mathrm{T}_{4}\right)$ was considered best in sensory and nutritional qualities and gooseberry could be successfully incorporated in fruit jams to enhance the nutritional properties of the food products.
\end{abstract}

\section{Keywords}

Fruits, Jams, Papaya, Gooseberry, Sensory and Nutritional Evaluation

\section{Introduction}

Among the perishable commodities fruits are the essential ingredients in the human dietaries. They are high in

How to cite this paper: Gupta, E., Purwar, S., Jaiswal, P., Chaturvedi, R. and Rai, G.K. (2016) Sensory Evaluation and Nutritional Composition of Developed Papaya-Gooseberry Jam. Food and Nutrition Sciences, 7, 600-608.

http://dx.doi.org/10.4236/fns.2016.77061 
nutritive value and make important nutritional contribution to human well being and they are cheaper and better sources of protective foods. They are naturally low in fat, sodium, calories and have absolutely no cholesterol and are a significant source of several fundamental nutrients, including dietary fiber, vitamin C, folate (folic acid), potassium, phyto-nutrients and many anti-oxidants like phenols, flavonoids and anthocyanins. These compounds protect the body from oxidative stress and degenerative diseases by developing the capacity to fight against ailments [1].

In different regions during certain parts of the year the perishable fruits are available as seasonal surplus and they create a glut in the market but in off-seasons they become scarce. If they are supplied in fresh or preserved form throughout the year for human consumption, the post harvest losses can be minimized and more variety of wholesome nutritious and acceptable foods will be available to the people [2].

The most common preserved fruit product is fruit-jams. Jams are solid gel prepared from ripe fruits and are one of the most important breakfast ingredients. Jams are of two kinds: one is prepared from a single fruit and another is prepared from a combination of two or more fruits [3]. Realizing the importance of fruit, as an economical, highly nutritious foodstuff and because of its perishable nature and seasonally availability, it was deemed necessary to make preserved products for human consumption throughout the year. Fruits like papaya (Carica papaya L.) and Indian gooseberry (Emblica officinalis) can be used to prepare a jam as they provide an abundant source of vitamins, minerals, fiber and antioxidants. Fruit jams are important in the diet of every age group as they provide quick boosts of energy with only half bout of calories. The presence of fiber and fructose content regulates the blood glucose levels by slowing the digestion and enhancing the satiety level. Good jam has a soft even consistency without distinct pieces of fruit, a bright color, a good fruit flavor and easy to spread semi-jel- lied texture without free liquid. This study was aimed at keeping in view the nutritional importance of papaya and gooseberry prolonging their utilizable lifespan by preserving them as jam along with an analysis of organoleptic acceptability.

\section{Materials and Methods}

\subsection{Fruit Selection}

Freshly mature papaya (Carica papaya L.) and gooseberry (Emblica officinalis) were purchased from the local market of Allahabad.

\subsection{Fruit Preparation}

Sorting and grading is essential to get suitable quality of fruit which was done by hand. The fruits were first thoroughly washed under running tap water to reduce soil, plant and debris load. Grading of fruit was done based on cleanliness, firmness, soundness, maturity, weight, color, size, shape, freedom from foreign matters, insect damage and mechanical injury. Undamaged fruits were selected with no symptoms of visible discoloration and soaked in warm water at $\left(80^{\circ} \mathrm{C}\right)$ for 2 min to reduce surface microbial load.

\subsection{Extraction of Fruit Pulp}

\section{a) Papaya (Carica papaya L.)}

From the graded papaya the pulp was extracted manually. It was homogenized in a mixer to obtain fine pulp.

\section{b) Gooseberry (Emblica officinalis)}

The washed gooseberry were boiled for $5 \mathrm{~min}$ in equal amount of water (by weight) to soften the outer skin. The boiled gooseberry were deseeded and pulped in a mixer; and the crude mixture pulp was sieved through an 800-micron sieve.

\subsection{Development of Jam}

The papaya-gooseberry jam was developed by incorporation of gooseberry pulp in different ratios as shown in Table 1. The entire experiment had one control $T_{0}$ (100\% papaya) and six variations $T_{1}$ (95:5), $T_{2}(90: 10), T_{3}$ (85:15), $T_{4}$ (80:20), $T_{5}$ (75:25) and $T_{6}$ (70:30) at different percent incorporation levels with gooseberry pulp which were replicated three times and each replication was tested for sensory evaluation by a panel of judges using 9-point Hedonic Scale. 
Table 1. Different ratios of papaya and gooseberry pulp.

\begin{tabular}{ccc}
\hline Treatments & Papaya & Gooseberry \\
\hline $\mathrm{T}_{0}$ & 100 & 0 \\
$\mathrm{~T}_{1}$ & 95 & 5 \\
$\mathrm{~T}_{2}$ & 90 & 10 \\
$\mathrm{~T}_{3}$ & 85 & 15 \\
$\mathrm{~T}_{4}$ & 80 & 20 \\
$\mathrm{~T}_{5}$ & 75 & 25 \\
$\mathrm{~T}_{6}$ & 70 & 30 \\
\hline
\end{tabular}

\subsection{Preparation of Jam}

Fruits are preserved in the form of jam by relying upon the high solids-high acid principle. For the preparation of Jam fruit pulp was boiled with sufficient quantity of sugar to a reasonably thick consistency, firm enough to hold fruit issues in position [4].

Flow Chart for Papaya-Gooseberry Jam Preparation

Selection and preparation of fruit (papaya and gooseberry)

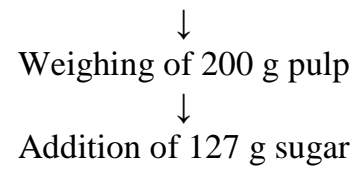

$\downarrow$

Cooking the pulp (cooking slowly with occasional stirring for 12 - 15 min)

$\downarrow$

Adding together citric acid $(1.7 \mathrm{~g})+$ salt $(1 / 2$ pinch $)+2$ g pectin

$\downarrow$

Judging the end point (TSS-68.5\% using refractometer ABBE)

$\downarrow$

Packing (filled the hot jam into clean, dry sterilized bottles)

$\downarrow$

Cooling, Capping and Storage (at ambient temperature)

\subsection{Chemical Analysis}

\subsubsection{Determination of Total Soluble Solids (TSS)}

The total soluble solids (TSS) of the fruit pulp and jam were determined using a hand refractometer ( $0 \%$ to $30 \%$ Brix, Model DIGT 0-30ATC for the pulp and 0 to 68\% Brix Model DIGT 0-68ATC (The Optical Instruments Co. Ltd, Japan) for jam.

\subsubsection{Proximate Analysis}

The proximate composition was analyzed according to the standard methods outlined by AOAC (2005) [5].

\section{1) Determination of Moisture}

$5 \mathrm{~g}$ of the sample was weighed and taken in a tare porcelain dish $\left(W_{1} \mathrm{~g}\right)$. Then dish was shaken till the contents were evenly distributed and placed in hot air oven, maintained at $105^{\circ} \mathrm{C} \pm 2{ }^{\circ} \mathrm{C}$ and dried for at least 2 hours. It was then cooled in desiccators and lowest weight was noted $\left(W_{2} g\right)$.

Calculation: Percent moisture content $=\frac{\text { loss in weight }}{\text { Initial weight of the sample }} \times 100=\frac{W_{1}-W_{2}}{W_{1}-W} \times 100$

Tared weight of the dish ( $W$ g);

Weight of dish with samples $\left(W_{1} g\right)$; 
Weight of the dish + sample after drying in oven $\left(W_{2}\right.$ g).

\section{2) Determination of Total Ash}

Ash comprises of the mineral content which was present in the sample which can be determined by igniting unknown amount of dried material in a muffle furnace. The dried material obtained from determination of moisture in a crucible dish was ignited on a blue flame of a burner till the smoke was given off. The porcelain/ crucible dish was then heated in a muffle furnace maintained at $500^{\circ} \mathrm{C} \pm 5^{\circ} \mathrm{C}$ for $1-2$ hours. It was cooled in a desecrator and weight was taken.

Calculation: Percentage of Ash $=\frac{\text { Weight of dish after ignition }}{\text { Weight of sample }} \times 100=\frac{W_{3}-W}{W_{1}-W} \times 100$

Weight of the dish + weight of dried sample $=\left(W_{2} g\right)$;

Weight of dish + weight of ash $=\left(W_{3} g\right)$.

\section{3) Determination of Protein}

$5.0 \mathrm{~g}$ of sample was accurately weighed in a cupped filter paper and transfer the contents of filter paper into the kjeldahl flask. $10 \mathrm{~g}$ of digestion mixture $\left(\mathrm{CuSO}_{4}+\mathrm{K}_{2} \mathrm{SO}_{4}+\right.$ Selenium oxide) and $25 \mathrm{ml}$ of concentrated $\mathrm{H}_{2} \mathrm{SO}_{4}$ was added. It was slowly warmed to minimize frothing, and then boiled until the solution was clean. The solution was allowed to cool and transferred to a $100 \mathrm{ml}$ volumetric flask and make up the volume using distilled water. In the receiver of distillation apparatus, $10 \mathrm{ml}$ of aliquot and $10 \mathrm{ml}$ of $40 \%$ sodium hydroxide was added. Released ammonia was collected in $25 \mathrm{ml}$ of $4 \%$ boric acid solution containing few drops of mixed indicator (Mixed indicator gives pink on distillation) which was distilled for half an hour, afterwards condenser outlet was disconnected. The obtained boric acid solution was titrated with $0.01 \mathrm{~N}$ sulphuric acid or $0.01 \mathrm{~N} \mathrm{Hy-}$ drochloric acids and for the blank water or sucrose was used in place of sample.

Calculation: $1 \mathrm{ml}$ of $0.01 \mathrm{~N} \mathrm{H}_{2} \mathrm{SO}_{4}$ for $=0.0014 \mathrm{~g}$

Titre volume $=\mathrm{A}-\mathrm{B} \mathrm{ml}$

$$
\text { Percentage nitrogen }=\frac{A-B \times 0.001}{W} \times \frac{V}{V_{1}} \times 100
$$

$\%$ crude protein $=N \times$ conversion factor (6.25);

Volume of $0.1 \mathrm{~N} \mathrm{H}_{2} \mathrm{SO}_{4}$ for sample $=A$;

Volume of $0.1 \mathrm{~N} \mathrm{H}_{2} \mathrm{SO}_{4}$ for blank $=B$;

Weight of sample $=W=2 \mathrm{gm}$;

Volume made $(V)=100 \mathrm{ml}$;

Aliquot distilled $\left(V_{1}\right)=10 \mathrm{ml}$.

\section{4) Determination of Crude Fat}

The extraction flask was weighed accurately ( $\mathrm{W}_{1} \mathrm{~g}$ ) and $2 \mathrm{~g}$ of the sample was transferred into the extraction thimble and was carefully placed in the extractor so that it was within its siphon height. Weighed extraction flask was connected to the extractor carrying the thimble and sufficient amount of petroleum ether was poured into the extractor to start the siphon and then filled about half the extraction flask. Extractor was connected to the condenser and flask was heated on a water bath or electric mental for 3 hours. The heat vaporizes the solvent and condensed in the condenser. The condensed solvent falls drop-wise into the thimble. The solvent extracts the fat present in the food. When the level of the solvent reached the siphon height, the whole of the ether flowed down into the flask below taking along with the extracted fat behind and the process was repeated. At the end of 3 hours by which time, at least 10 - 15 siphoning was taken, flask was removed carefully. The extract was transferred in a tarred conical flask and solvent was evaporated. Cooled in desiccators and weighed $\left(W_{1} \mathrm{~g}\right)$. Drying, cooling and weighing or successive weighing not diffixing by more than $0.0002 \mathrm{~g}$ were obtained. Finally the weight was recorded $\left(W_{2}\right.$ g). Percentage of ether extract was calculated by multiplying the increase in weight of the extraction flask by 100.

Calculation: Percentage fat in sample $=\frac{W}{W_{2}-W_{1}} \times 100$

Weight of sample $(W)$;

Weight of flask $\left(W_{1}\right)$;

Weight of flask + fat $\left(W_{2}\right)$;

(Weight of flask + fat $)-($ Weight of flask $)=\left(W_{2}-W_{1}\right)$. 


\section{5) Determination of Crude Fiber}

$2 \mathrm{~g}$ of dried, fat free residue obtained after crude fat determination was weighed accurately and transferred into the one-liter conical flask. In a beaker, brought to boil the $200 \mathrm{ml}$ dilute sulphuric acid (1.25\%) and pour the boiling acid into the flask. The contents of the flask were boiled exactly for 30 minutes with constant shaking and the liquid level was maintained during boiling. At the end of 30 minutes remove the flask and filter its contents through fine lined pad held in a funnel and wash with boiling water until the washing are no longer acid to litmus.The entire residues was transferred back to the original digestion flask or beaker with a spatula and wash the residue on the linen into the digestion flask with $200 \mathrm{ml}$ of boiling dilute $\mathrm{NaOH}$ (1.25\%). The digestion flask was again boiled for exactly 30 minutes with constant rotation and maintained the liquid level as before. At the end of the specified period, the residue was washed thoroughly with boiling water till free from alkali and transferred to the prepared gooch crucible dried to constant weigh at $105^{\circ} \mathrm{C}$ in an hot air oven (W g). The residue was again washed with $15 \mathrm{ml}$ of $95 \%$ ethyl alcohol. The content in gooch crucible was dried at $105^{\circ} \mathrm{C}$ and cooled in desiccators and weighed to constant weight $\left(\mathrm{W}_{1} \mathrm{~g}\right)$. The gooch crucible and its contents were transferred in a muffle furnace and ignited at $600^{\circ} \mathrm{C} \pm 20^{\circ} \mathrm{C}$ for 1 hour, until all carbonaceous matter is burnt. Finally, cooled the gooch crucible containing the ash in desiccators and weighed $\left(\mathrm{W}_{2} \mathrm{~g}\right)$.

Calculation: Percentage of crude fiber $=\frac{\left(W_{1}-W\right)-\left(W_{2}-W\right)}{2} \times 100$

Tare weight of Gooch crucible $=(W \mathrm{~g})$;

Weight of Gooch crucible + sample $($ ash $)=\left(W_{2} g\right)$;

Weight of residue $=\left(W_{2}-W\right)$ g.

6) Determination of Carbohydrate

Total carbohydrate by difference was calculated by subtracting the sum of percentage of protein, fat, ash and moisture. Carbohydrate was divided into two groups' crude fiber and nitrogen free extract (NFE). Total carbohydrate include crude fiber also, but NFE was calculated by subtracting the sum of percentage of ash, crude fiber, fat, protein and moisture from hundred.

Calculation: $($ Percent $)=100-[$ Moisture $(\%)+$ Crude fiber $(\%)+\operatorname{Ash}(\%)+$ Fat $(\%)+$ Protein $(\%)]$

7) Determination of Caloric Value

Energy value of the sample was calculated by multiplying the figure for percentage of protein, fat and carbohydrate by 4,9 and 4 respectively and adding the figures obtained.

Calculation: Calorific value $(\mathrm{Kcal} / \mathrm{g})=(\%$ protein $\times 4)+(\%$ fat $\times 9)+(\%$ carbohydrate $\times 4)$

\subsubsection{Mineral Analysis}

The mineral composition was analyzed according to the standard methods as described in Ranganna [6].

1) Determination of Calcium

$10 \mathrm{~g}$ of ash sample was taken and $5 \mathrm{ml}$ of concentrated hydrochloric acid was added to rinse the upper part of dish and evaporated to dryness. The residue was dissolved by adding $2 \mathrm{ml}$ of hydrochloric acid. Covered it with watch glass and filtered the ash solution into $100 \mathrm{ml}$ volumetric flask and diluted to $100 \mathrm{ml}$ volume. $50 \mathrm{ml}$ of ash solution was taken in a $250 \mathrm{ml}$ conical flask and 8 - 10 drops of bromocresol green indicator solution was added gradually. $20 \%$ of sodium acetate was added until the solution turns blue ( $\mathrm{pH}$ at this point was $4.8-5.0$ ) covered with watch glass and heated to boiling. Slowly add $3 \%$ of oxalic acid drop wise, until the color of solution was green ( $\mathrm{pH}$ at this point should be 4.4 to 4.6 which is optimum for precipitation of calcium oxalate). Continue boiling for one minute and allow it to stand until clear or overnight. The supernatant solution was filtered and discarded through Whatman no. 42 filter paper. Wash the conical flask and precipitate, filter it with $50 \mathrm{ml}$ of dilute ammonium hydroxide solution, using small portions at a time then again wash it with some hot distilled water. Lastly, the filter paper was washed with a mixture of $125 \mathrm{ml}$ distilled water and $5 \mathrm{ml}$ concentrated sulphuric acid breaking the tip of filter paper and collecting the washing in original empty conical flask. Heat the solution to $90^{\circ} \mathrm{C}$ and titrated with $0.1 \mathrm{~N}$ potassium permagnate solution until pink color was obtained.

Calculation: $1 \mathrm{ml}$ of $0.1 \mathrm{~N} \mathrm{KMnO}_{4}=2 \mathrm{mg}$ Calcium

$$
\text { mg calcium in } 100 \mathrm{~g} \text { of sample }=2 \times(A-B) \times \frac{V_{1}}{V} \times \frac{100}{W}
$$

Weight of the sample $(W)=5 \mathrm{~g}$; 
Volume of ash solution made $(V)=100 \mathrm{ml}$;

Volume of ash solution used $\left(V_{1}\right)=50 \mathrm{ml}$;

Volume of $0.1 \mathrm{~N} \mathrm{KMnO}_{4}$ used for sample $=A$;

Volume of $0.1 \mathrm{~N} \mathrm{KMnO}_{4}$ used for blank $=B$.

\section{2) Determination of Phosphorous}

Phosphorus reacts with molybdic acid to form phosphomolybdate complex. It is then reduced with aminonaphthol-sulphuric acid to complex molybdenum blue, which is measured at 650nm.In 5 ml of ash solution, 5 $\mathrm{ml}$ of molybdate reagent and $2 \mathrm{ml}$ of aminonaphthol-sulphonic acid solution was added and the volume make up with distilled water to $50 \mathrm{ml}$. The blank was similarly prepared by using distilled water in place of the sample. The solution was incubated for 10 minutes and the absorbance was measured at $650 \mathrm{~nm}$ setting blank at $100 \%$ transmission.

$$
\text { Phosphorous (mg/100g) }
$$

Calculation:

O.D. Of sample $\times$ Total vol. of ash solution $\times 0.01$

$=\overline{\text { O.D. of std. solution } \times \text { Vol. of ash taken for estimation } \times \text { Weight of sample taken for estimation }}$

3) Determination of Ascorbic Acid (Vitamin C)

This method is based upon the reduction of the dye 2-6 dicholoro-phenol endophenol by an acid solution of ascorbic acid in the absence of interfering substance $\left(\mathrm{Cu}^{++}, \mathrm{Fe}++\right.$, and $\mathrm{Sn}++$, etc.). The reduction capacity of the extract of the sample is directly proportional to the ascorbic acid content.

For the preparation of standard, $20 \mathrm{mg}$ of pure ascorbic acid was accurately weighed on a tared black glazed paper and transferred to a clean $100 \mathrm{ml}$ volumetric flask. Dissolve in 1\% oxalic acid solution and make up the volume to the mark with the same acid. For the preparation of dye indicator, 50mg of sodium salt of 2,6 dicholorophenol-endophenol was dissolved in $150 \mathrm{ml}$ of hot water containing $42 \mathrm{mg}$ of sodium carbonate. The solution was cooled and diluted with $200 \mathrm{ml}$ of distill water and stored in a glass bottle and kept in a refrigerator or away from sunlight at $3{ }^{\circ} \mathrm{C}$. For the standardization of dye solution, $5 \mathrm{ml}$ of ascorbic acid was pipette out in a conical flask and $5 \mathrm{ml}$ of $1 \%$ oxalic acid solution was added and titrated with the dye-indicator to a fame end point that persists beyond 15 seconds. The ascorbic acid equivalent of the dye was calculated in $\mathrm{mg} / \mathrm{ml}$.

$1 \mathrm{gm}$ of sample was weighed and dissolves in $10 \mathrm{ml}$ distilled water and filtered through muslin cloth.10ml of the filtrate was taken in a $100 \mathrm{ml}$ volumetric flask and diluted to the mark with 1\% oxalic acid solution. Filter the diluted solution through dry filter paper if necessary. Pipette out $10 \mathrm{ml}$ or $25 \mathrm{ml}$ aliquot of the filtrate into a small flask and titrate immediately with the standardized dye indicator solution to a pink end point.

Calculation: Ascorbic acid $\mathrm{mg} / 100 \mathrm{gm}=\frac{E V \times V_{1} \times 100}{V_{2} \times W}$

$E=$ Ascorbic acid equivalent of the dye in $\mathrm{mg} / \mathrm{ml}$;

$V=\mathrm{ml}$ of the dye indicator used in the titration (VR);

$V_{1}=$ Volume to which the fruit juice is diluted $(500 \mathrm{ml})$;

$V_{2}=$ Volume of filtrate taken for the titration $(10-20 \mathrm{ml})$;

$W=$ Weight or volume of fruit juice initially taken for the determination.

\section{4) Determination of Beta-Carotene}

Carotenoids are generally separated by chromatography. The method is based upon the separation of the biologically active carotenoid pigments from the total carotenoid pigment in an extract by using an adsorbent having varying affinities for the different pigments. $10 \mathrm{~g}$ of sample was in pastel mortar with $40 \mathrm{ml}$ acetone and filtered. $0.1 \mathrm{~g} \mathrm{MgO}_{2}$ diluted with $60 \mathrm{ml}$ of hexane was added in the above sample and filtered. The filtrate was transferred in a separating funnel and two layers were separated. Lower layer was decanted and the upper transparent layer of hexane was taken for estimation. The upper layer was transferred into a 100 ml volumetric flask and volume make up with $100 \mathrm{ml}$ hexane. For the preparation of column, aluminum and sodium sulphate was taken in 1:1 ratio $(20 \mathrm{~g}+20 \mathrm{~g})$. The silica gel was poured into the column using a $10 \mathrm{ml}$ beaker and the suction pump was used to force air into the column and pack the silica gel. A space of $4-5 \mathrm{~cm}$ was left on top of the adsorbent for the addition of solvent (hexanes and acetone).Hexanes and acetone solution was added to the top of the silica gel and when the bottom solvent level is at the bottom of the column, the pre-elution process is completed and the column is ready to load. The sample to be purified is dissolved in a small amount of solvent, such as hexanes or acetone and loaded into the column. The sample was collected in a beaker and the absorption was noted by using spectrophotometer at $436 \mathrm{~nm}$. 


$$
\text { Beta carotene(mcg/100g) }
$$

Calculation: $=\frac{\text { Concentration of carotene solution read as std. solution }(\mathrm{mcg} / 100 \mathrm{~g}) \times \text { Final dilute vol }}{\text { Weight of the sample }} \times 100$

\section{5) Percent Anti Radical Activity}

$10 \mathrm{mg}$ of sample is taken and $10 \mathrm{ml}$ of acidified methanol is added in the sample. It was heated on a water bath at $40^{\circ} \mathrm{C}$ for 20 minutes. It was filtered and the supernatant is centrifuged for two minutes. Finally the resulting supernatants were used as test samples. For the preparation of DPPH (2, 2-diphenyl-1-picrylhydrazyl) solution, $4.3 \mathrm{mg}$ of DPPH was dissolved in $3.3 \mathrm{ml}$ of methanol which was protected from light by covering the test tubes. Pure methanol was used as blank solution. $100 \mu \mathrm{l}$ of sample extract was taken in a test tube and diluted with $200 \mu \mathrm{l}$ of methanol. The volume make up with $2.7 \mathrm{ml}$ methanol again up to $3 \mathrm{ml}$. Then $150 \mu \mathrm{l}$ of DPPH solution was added and test tubes were covered with brown paper or aluminum foil and mixed properly. The solution was incubated for 15 minutes at room temperature and the absorbance was recorded at $515 \mathrm{~nm}$ by spectrophotometer [7].

The free radical scavenging activity (FRSA) (\% antioxidant activity) was calculated by using the following equation:

$$
\% \text { anti radical activity }=\frac{\text { Control absorbance }- \text { Sample absorbance }}{\text { Control absorbance }} \times 100
$$

\subsection{Organoleptic Evaluation}

The developed papaya-gooseberry jams were served to $30 \mathrm{semi}$ trained panelists group for evaluating color, consistency, flavor, taste, and overall acceptability on a 9 point hedonic scale with a scores ranging from 9 to 1 which represents like extremely and dislike extremely respectively. The quality parameters were quantified and the mean scores of the three evaluations were calculated.

\subsection{Statistical Analysis}

The collected data was analyzed and tabulated statistically and expressed as percentage; mean scores, standard error of mean, critical difference, t-test and one-way analysis of variance (ANOVA) by using statistical software SPSS version 12.0. To indicate statistically significant difference $P \leq 0.05$ values were considered.

\section{Results and Discussion}

\subsection{Organoleptic Evaluation of Developed Jam}

The treatment $\mathrm{T}_{4}$ had the highest sensory scores for color (8.81), consistency (8.79), flavor (8.49), taste (8.84) and overall acceptability (8.78) than Control $\mathrm{T}_{0}$ and other treatments, making it quite obvious that the addition of 20 percent gooseberry increase the color, consistency, flavor, taste and overall acceptability of the jam. The other levels of incorporation were also liked at various degrees, although a little less than treatment $T_{4}$. From the ANOVA table, it was evident that there was significant difference $(p \leq 0.05)$ between various treatments regarding the overall acceptability of the product. In general, addition of pectin had no significant $(p>0.05)$ effect on the color of the jams produced. The organoleptic scores of developed papaya-gooseberry jam were shown in Table 2. Jain et al. [8] observed the decrease in the overall acceptability of guava and papaya pulp with increase in storage period.

\subsection{Nutritional Composition of Developed Jam}

On the basis of sensory evaluation the best treatment of the developed papaya- gooseberry jam i.e., $\mathrm{T}_{4}$ with 80 percent of papaya and 20 percent gooseberry were identified and the chemical analysis of the treatment $\left(\mathrm{T}_{4}\right)$ in comparison to control $\left(\mathrm{T}_{0}\right)$ were carried out with reference to moisture, protein, fat, carbohydrate, fiber, ascorbic acid, calcium, phosphorous, beta-carotene and antioxidant activity. The data pertaining to nutritive value of developed papaya gooseberry jam is presented in Table 3 . The moisture content was high in prepared jam $\mathrm{T}_{4}$ (20.30\%) than in control $\mathrm{T}_{0}(11.09 \%)$. The maximum energy value $353 \mathrm{Kcal} / 100 \mathrm{~g}$ was observed in treatment $\mathrm{T}_{0}$ (control). On comparing the protein, fat and carbohydrate content of the developed jam, it was found to be high- 
Table 2. Average organoleptic scores of different parameters in control and best treatment of papaya-gooseberry jam.

\begin{tabular}{cccccc}
\hline \multirow{2}{*}{$\begin{array}{c}\text { Sensory } \\
\text { characteristics/ } \\
\text { Treatments }\end{array}$} & Color & Consistency & Flavor & Taste & Overall acceptability \\
\cline { 2 - 6 } $\mathrm{T}_{0}($ Control) & $8.11 \pm 0.77$ & $8.10 \pm 0.56$ & $8.26 \pm 0.61$ & $8.07 \pm 1.01$ & $8.13 \pm 0.08$ \\
$\mathrm{~T}_{1}(5 \%)$ & $7.10 \pm 0.68$ & $7.05 \pm 0.63$ & $7.14 \pm 0.85$ & $7.08 \pm 0.69$ & $7.09 \pm 0.03$ \\
$\mathrm{~T}_{2}(10 \%)$ & $7.14 \pm 1.13$ & $7.49 \pm 0.91$ & $7.58 \pm 1.00$ & $7.52 \pm 1.14$ & $7.43 \pm 0.19$ \\
$\mathrm{~T}_{3}(15 \%)$ & $7.76 \pm 1.13$ & $6.19 \pm 0.60$ & $6.95 \pm 1.06$ & $7.45 \pm 1.53$ & $7.08 \pm 0.68$ \\
$\mathrm{~T}_{4}(20 \%)$ & $8.81 \pm 0.36$ & $8.79 \pm 0.57$ & $8.49 \pm 0.85$ & $8.84 \pm 0.30$ & $8.78 \pm 0.20$ \\
$\mathrm{~T}_{5}(25 \%)$ & $7.68 \pm 0.65$ & $7.61 \pm 0.71$ & $7.61 \pm 0.71$ & $7.56 \pm 0.79$ & $7.61 \pm 0.49$ \\
$\mathrm{~T}_{6}(30 \%)$ & $6.98 \pm 0.62$ & $6.91 \pm 0.63$ & $6.93 \pm 0.62$ & $7.03 \pm 0.66$ & $6.96 \pm 0.05$ \\
F value & $6.510^{*}$ & $15.723^{*}$ & $5.472^{*}$ & $4.805^{*}$ & $21.729^{*}$ \\
CD $(P=0.05)$ & 0.335 & 0.423 & 0.079 & 0.313 & 0.330 \\
\hline
\end{tabular}

9-point hedonic scale is as follows: 1 -dislike extremely, 2-dislike very much, 3-dislike moderately, 4-dislike slightly, 5-neither like or dislike, 6 -like slightly, 7-like moderately, 8-like very much, 9-like extremely. * Significant difference is at 0.05 levels. Values are means ( \pm SEM).

Table 3. (a) Proximate Composition (per $100 \mathrm{~g}$ ) in control $\left(\mathrm{T}_{0}\right)$ and best treatment $\left(\mathrm{T}_{4}\right)$ of developed papaya-gooseberry jam. (b) Mineral and Vitamin Composition (per $100 \mathrm{~g}$ ) and Percent Anti-Radical Activity (\%) in control $\left(\mathrm{T}_{0}\right)$ and best treatment $\left(\mathrm{T}_{4}\right)$ of developed papaya-gooseberry jam.

(a)

\begin{tabular}{ccccccc}
\hline \multirow{2}{*}{ Treatments } & \multicolumn{5}{c}{ Nutrients } \\
\cline { 2 - 7 } & Moisture (\%) & Energy (kcal) & Protein (g) & Fat (g) & Carbohydrate (g) & Fiber (g) \\
\hline $\mathrm{T}_{0}$ & $11.09 \pm 0.95$ & $353 \pm 1.57$ & $0.50 \pm 0.10$ & $0.19 \pm 0.01$ & $87.14 \pm 10.0$ & $0.60 \pm 0.10$ \\
$\mathrm{~T}_{4}$ & $20.30 \pm 0.10$ & $314 \pm 10.01$ & $0.30 \pm 0.10$ & $0.18 \pm 0.01$ & $72.67 \pm 11.0$ & $1.32 \pm 0.10$ \\
t-value & $15.586^{*}$ & $6.575^{*}$ & 2.449 & 0.756 & 1.684 & $8.818^{*}$ \\
\hline
\end{tabular}

(b)

\begin{tabular}{cccccc}
\hline \multirow{2}{*}{ Treatments } & \multicolumn{4}{c}{ Nutrients } \\
\cline { 2 - 5 } & Calcium (mg) & Phosphorus (mg) & Vitamin-C (mg) & Beta carotene ( $\mu$ g) & Percent anti radical activity (\%) \\
\hline $\mathrm{T}_{0}$ & $36.0 \pm 10$ & $10.13 \pm 1.0$ & $9.03 \pm 1.0$ & $195.0 \pm 5.0$ & $88.0 \pm 1.0$ \\
$\mathrm{~T}_{4}$ & $92.0 \pm 2.0$ & $14.13 \pm 1.0$ & $19.16 \pm 1.0$ & $156.0 \pm 10.0$ & $98.0 \pm 1.0$ \\
$\mathrm{t}$-value & $9.511^{*}$ & $4.773^{*}$ & $12.14^{*}$ & $6.042^{*}$ & $12.247^{*}$ \\
\hline
\end{tabular}

*Significant difference is at 0.05 levels.

est in treatment $\mathrm{T}_{0}(0.50 \mathrm{~g} / 100 \mathrm{~g}, 0.19 \mathrm{~g} / 100 \mathrm{~g}$ and $87.14 \mathrm{~g} / 100 \mathrm{~g})$. Papaya fruit is a good source of balanced nutrients it contains significantly high amount of energy and carbohydrates (i.e. 15.15\% sugar and $42.28 \%$ starch in pulp) but is low in protein and fat [9]. Greatest amount of fiber content was observed in treatment $\mathrm{T}_{4}(1.32$ $\mathrm{g} / 100 \mathrm{~g}$ ) due to incorporation of gooseberry which is effective in controlling oxidation of low density lipoproteins (LDL) which releases free radicals and cause coronary artery disease or atherosclerosis. The treatment $\mathrm{T}_{4}$ was found to have maximum calcium, phosphorus and vitamin C content $(92.0 \mathrm{mg} / 100 \mathrm{~g}, 14.13 \mathrm{mg} / 100 \mathrm{~g}$ and $19.16 \mathrm{mg} / 100 \mathrm{~g})$ in comparison to control $\left(\mathrm{T}_{0}\right)$. Calcium and phosphorus are the major minerals needed by the body which plays a major role in maintaining fluid and electrolyte balance around the body and within the cells. Together they help in mineralization of bone tissue which helps in increasing the bone mineral density. The high vitamin $\mathrm{C}$ content was due to incorporation of gooseberry which is packed with polyphenols, vitamins and pig- 
ment antioxidants. It has a protective effect on the membrane of erythrocytes which helps in improving the blood circulation in the arteries and also facilitate in better absorption of iron in the human body [10]. Beta-carotene content was found to be greatest in treatment $\mathrm{T}_{0}$ (control) $(195.0 \mu \mathrm{g} / 100 \mathrm{~g}$ ). The selection of 100 percent papaya might be one of the contributing factors for higher beta-carotene content in control. In fruits the presence of vitamin $\mathrm{A}$ is in the form of carotenes $(\alpha, \beta$ and $\gamma$ ) which is converted into vitamin inside the body, its deficiency results in impairment of immune system, hematopoiesis and typical ocular effects (eg, xerophthalmia, night blindness) [11]. It is well recognized fact that fruits are rich in antioxidants. The percent anti-radical activity was found to be highest in treatment $\mathrm{T}_{4}(98.0 \%)$ than treatment $\mathrm{T}_{0}$ (control) $(88.0 \%)$. Antioxidantis a powerful substance that comes from fresh fruits and it is helpful in preventing damaging effects of oxidation on cells caused by free radicals. Adetuyi et al. [12] reported that in two storage temperature, shea butter waxed papaya retains more antioxidant (total phenol, vitamin $\mathrm{C}$, carotenoid and tocopherol) than unwaxed papaya. The results revealed that there was a significant difference $(p \leq 0.05)$ in moisture, energy, fiber, calcium, phosphorus, vitamin $\mathrm{C}, \beta$-carotene and antioxidant activity whereas no significant difference $(P \leq 0.05)$ was observed in case of protein, fat and carbohydrate content between treatment $\mathrm{T}_{0}$ (papaya jam) and $\mathrm{T}_{4}$ (papaya-gooseberry jam).

\section{Conclusion}

From the results summarized above, it can be concluded that the incorporation of gooseberry pulp in papaya jam can improve the nutritional quality of product and add variety in the diet. The treatment $\left(\mathrm{T}_{4}\right)$ incorporated with 20 percent gooseberry was considered best in sensory and nutritional qualities and showed good impact on nutritive value with regards to fiber, calcium, vitamin $\mathrm{C}$, phosphorous and anti-radical activity than control $\left(\mathrm{T}_{0}\right)$. Therefore, the developed papaya-gooseberry jam can be included in the daily diet of every age group which can definitely increase sensory attribute and nutrient intake by maintaining the good health and promoting immunity against infections. Thus the developed papaya-gooseberry jam is found to be acceptable in both sensory attributes and nutritional quality.

\section{References}

[1] Yoshikawa, T., Toyokuni, S., Yamamoto, Y. and Naito, Y. (2000) Free Radicals in Chemistry Biology and Medicine. OICA International, London

[2] Agarwal, G. and Mangaraj, S. (2005) Studies on Physico-Chemical Changes in Selected Fruits during Storage. Beverage and Food World, 32, 72-75.

[3] Manay, S.N. and Shadaksharaswamy, N. (2005) Foods, Facts and Principles. New Age International (P) Limited, New Delhi, 197.

[4] Narain, A. and Vidhya, R. (2010) Development of Preserve Products (Jam and Fruit Bar). African Journal of Food Science and Technology, 1, 51-57.

[5] AOAC (2005) Determination of Moisture, Ash, Protein and Fat. Official Method of Analysis of the Association of Analytical Chemists. 18th Edition, AOAC, Washington DC.

[6] Ranganna, S. (2001) Hand Book of Analysis and Quality Control for Fruits and Vegetable Products. 7th Edition, Tata McGraw Hill Book Co., New Delhi, 594-625.

[7] Muanda, N.F., Koné, A., Dicko, D., Soulimani, R. and Younos, C. (2011) Phytochemical Composition and Antioxidant Capacity of Three Malian Medicinal Plant Parts. Evidence-Based Complementary and Alternative Medicine, 2011, Article ID: 674320.

[8] Jain, P.K., Jain, P. and Nema, K.P. (2011) Quality of Guava and Papaya Fruit Pulp as Influenced by Blending Ratio Storage Period. America Journal of Food Technology, 6, 507-512. http://dx.doi.org/10.3923/ajft.2011.507.512

[9] Bari, L., Hassan, P., Absar, N., Haque, M.E., Khuda, M., Pervin, M.M., et al. (2006) Nutritional Analysis of Two Local Varieties of Papaya (Carica papaya L.) at Different Maturation Stages. Pakistan Journal of Biological Sciences, 9 , 71-76.

[10] Oboh, G. (2005) Effect of Blanching on the Antioxidant Property of Some Tropical Green Leafy Vegetables. Lebensmittel-Wissenschaft \& Technologie, 38, 513-517. http://dx.doi.org/10.1016/j.lwt.2004.07.007

[11] Umoh, I.B. (1998) Commonly Used Fruits in Nigeria. In Osagie, A.U. and Eka, O.U., Eds., Nutritional Quality of Plant Foods, Post Harvest Research Unit, University of Benin, Benin City, 221-244.

[12] Adetuyi, F.O., Ayileye, T.A. and Dada, I.B.O. (2008) Comparative Study of Quality Changes in Shea Butter Coated Pawpaw Carica papaya Fruit during Storage. Pakistan Journal of Nutrition, 7, 658-662. http://dx.doi.org/10.3923/pjn.2008.658.662 


\section{Submit or recommend next manuscript to SCIRP and we will provide best service for you:}

Accepting pre-submission inquiries through Email, Facebook, Linkedin, Twitter, etc A wide selection of journals (inclusive of 9 subjects, more than 200 journals)

Providing a 24-hour high-quality service

User-friendly online submission system

Fair and swift peer-review system

Efficient typesetting and proofreading procedure

Display of the result of downloads and visits, as well as the number of cited articles

Maximum dissemination of your research work

Submit your manuscript at: http://papersubmission.scirp.org/ 